\title{
Health conditions in a population living near an industrial waste recycling plant in Mexico'
}

\author{
Horacio Tovalín Ahumada²
}

\begin{abstract}
The present study was conducted in a population living near a recycling plant for zinc and other metallic dusts to determine whether exposures to these substances were occurring and producing adverse health effects. The plant is situated in a suburb of Monterrey, which is the third most populous city in Mexico and the second most industrialized.

A cross-sectional study design was used for the investigation, which was carried out from September 1994 to November 1994. Using cluster sampling procedures, homes in two areas were selected - one exposed through proximity to the plant, and the other unexposed to serve as a control-until the desired sample size was achieved (621 individuals, with an average of five per dwelling). A specially trained psychology student administered a questionnaire to an adult member of each family, soliciting data on the presence of acute and chronic infections, complications of pregnancy, and congenital diseases among the family members.

One hundred twenty-seven questionnaires were administered in the exposed population, yielding information on 596 individuals. In the unexposed population, 147 questionnaires were administered furnishing data on 743 individuals. The sex and age distributions of the two populations were similar. The unexposed population had a slightly longer average duration of residence.

The most common health problems in the exposed population were irritation of the eyes and upper respiratory tract, allergies, sleep disturbances, bronchitis, excessive fatigue, skin problems, otitis, and anemia. The exposed population had significantly higher risks for skin eruptions and diseases, excessive fatigue, sleep disturbances, upper respiratory infections, otitis, bronchitis, and allergies. Exposed and unexposed women had comparable prevalences of obstetrical problems, spontaneous abortions, congenitally malformed offspring, and low birthweight. The questionnaire used to detect health problems has low sensitivity and may have generated underestimates of some conditions. Nevertheless, the analysis controlled for several different biases, and thus it can be concluded that a positive association exists between environmental exposure to these wastes and increased risk of disease.
\end{abstract}

1 Published in Spanish in this journal (Vol. 3, No. 1, 1998) with the title "Condiciones de salud de la población vecina a una planta recicladora de residuos en México."

2 Universidad Nacional Autónoma de México, Faculdad de Estudios Superiores-Zaragoza, México. Requests for reprints should be directed to the author at J.M. Parras, No. 271, Edificio 312 A-402, Colonia Juan Escutia, México DF, C.P. 09110, México. The author can also be contacted by email at: tovalin@servidor.unam.mx
To date few studies have investigated the health effects which populations may incur through environmental exposure to a number of waste products and to emissions from factories where these products are recycled, treated, warehoused, or used as raw materials. The circumstances in which these exposures occur make such studies difficult. In contrast to occupational exposures, in which workers come into contact with high levels of toxic substances, the concentrations associated with environmental exposures tend to be low (1).

Nevertheless, currently available data show that incidental exposures to certain toxic substances in industrial wastes can be harmful to the health of individuals living near the sites where 
these substances are used as raw materials. The observed toxicities vary in type and severity. Among the more prominent are general malaise, respiratory problems, skin cancers and other skin diseases $(2,3)$, leukemias $(4$, $5)$, congenital malformations (6), low birthweight (7), liver dysfunction, arterial hypertension, hernia, disturbances of mood and personality, and genetic mutations (8).

As industry is supervised no more stringently in Mexico than elsewhere, it is reasonable to suppose that these exposure-related illnesses occur there, too. Moreover, since the approval of the North American Free Trade Agreement, one may anticipate greater importation of toxic substances into the country for use as raw materials for production processes or for incineration. These considerations underlie the need to establish monitoring systems in order to prevent deleterious effects on the health of the population and the environment (9).

The present study was conducted in a population living near a plant that recycled zinc and other metallic dusts retained in the antipollution devices of plants producing steel from scrap metals, as well as other industrial wastes. Residents of the area near the plant had complained to the authorities that its emissions were making them sick.

The toxic substances associated with the processes for recovering dusts from a steelworks are, in addition to zinc, arsenic, lead, cadmium, copper, chrome, and nickel $(10,11)$, together with organic compounds that vary depending on the raw materials utilized. Some of these substances are known carcinogens. For example, arsenic is associated with cancer of the skin and lung, depending on the route of exposure. Chrome is associated with lung cancer, allergic reactions, and perforation of the mucosa and nasal septum. Nickel has been associated with cancer of the paranasal sinuses and lung, asthma, and allergies. Lastly, cadmium has been associated with lung cancer, bronchitis, emyphysema, nephropathy, prostate conditions, arthritis, early menopause, and-with very high exposuresosteomalacia (12-15).

Another toxic substance present in steelworks residues is lead. Its principal harmful effects in populations exposed through the environment are focused in the nervous system. In children, lead causes neuropsychological changes, and in adults, hematologic, cardiovascular, and renal disorders (16). The most important source of environmental exposure to lead is tetraethyl lead in gasoline. It has been shown, moreover, that ground contaminated with this metal becomes a permanent source of reexposure $(17,18)$.

In considering the effects of these substances, it is important to note that industrial emissions present in the air, water, and rain constitute a veritable "toxic soup" whose combined effects on health remain unknown.

The toxic substances of interest here may come into contact with a population when winds and rains stir up contaminated smoke and dust and carry them into dwellings. Once indoors, the substances may remain for long periods, contaminating food and beverages. When deposited in permeable soils, they may contaminate groundwater. As these pollutants circulate via a variety of environmental channels, they may penetrate organisms through the respiratory tract, digestive system, and sometimes, particularly in children, the skin. When expectant mothers are exposed, contaminants can cross the placenta and affect the fetus (19). These diverse sources and routes of exposure can be found wherever factories lack efficient antipollution systems or wastes accumulate on factory premises $(20,21)$.

Along with certain acute illnesses and ailments, the health effects associated with environmental exposure to toxic substances include various nonspecific manifestations of a chronic character. Thus it was considered important to learn the frequency with which these latter conditions occurred in the population of the state of Nuevo Léon, Mexico, where the present study was conducted.

In 1994, the principal causes of mortality in this state were heart disease, cancer, accidents, and diabetes mellitus. The most frequently reported tumors during the same year were leukemias and pulmonary, gastric, and breast cancers. The death rates from leukemia and pulmonary and breast cancer were higher than the national rates (22) (Table 1). These data suggest that the population has illnesses that may be associated with environmental pollution, and warrant an assessment of whether the high rates are indeed attributable to

TABLE 1. Mortality rates (per 100000 inhabitants) in the state of Nuevo León and in Mexico, 1986

\begin{tabular}{lcc}
\hline & \multicolumn{2}{c}{ Mortality rate } \\
\cline { 2 - 3 } \multicolumn{1}{c}{ Cause of death } & Nuevo León & Mexico \\
\hline Circulatory & 87.4 & 67.5 \\
Heart disease & 28.0 & 25.2 \\
Cancer & 61.1 & 51.6 \\
Trachea, bronchus, lung & 10.7 & 6.5 \\
Breast & 4.8 & 3.1 \\
Stomach & 4.2 & 5.2 \\
Leukemias & 3.1 & 3.0 \\
Accidents & 43.8 & 41.4 \\
Diabetes mellitus & 32.3 & 33.7 \\
Congenital malformation & 9.9 & 10.3 \\
Bronchitis & 4.5 & 9.2 \\
Asthma & 1.4 & 2.6 \\
\hline
\end{tabular}

Source: Instituto Nacional de Estadística, Geografía e Informática. Tabulaciones por defunciones. México, D.F.: INEGI; 1990 (Ref. 22). 
toxic substances associated with local industries.

\section{MATERIALS AND METHODS}

The study population consisted of residents in an area near a recycling plant for dangerous wastes from a steel mill. The area is located in a town near Monterrey, the third most populous city in Mexico and the second most industrialized.

A cross-sectional study design was employed. Two groups were identified-one of persons potentially exposed to the polluting substances through residing in close proximity to the factory, and the other of unexposed persons (23) —and their health status was evaluated once between September and November 1994. Residents of the exposed area were socioeconomically middle class (many heads of family were professionals), with houses of good or luxurious quality and access to all services. The residents of a marginal community near the factory were excluded from the study for lack of a group that was sufficiently comparable to serve as controls. The mill is the only industrial installation in the area, which has little vehicular traffic. The control group consisted of individuals with characteristics similar to the exposed group, except that they resided south of Monterrey, outside the industrial zone.

Sample sizes were calculated using the method of Fleiss (24). The following parameters were elected: level of statistical significance, 0.05; statistical power, 0.9; probability of detecting certain signs and symptoms associated with exposure to the toxic substances under study, 0.10 among the exposed and 0.05 among the unexposed. With these parameters, a sample size of 621 individuals is considered representative of the population. The unit of study was a household in the study area. A household was considered to consist of a group of individuals living under the same roof and dependent upon a single income; therefore, there might be more than one household per dwelling if the inhabitants depended on more than one income. As it was estimated that the average household had 5 members, the sample size of 621 individuals was divided by 5 to yield a total of 124 family questionnaires. This number was increased to 130 to allow for absentees and nonresponders.

Lacking a sampling frame for the households in the study area, a quota sampling method was used, with the goal of including all the houses in the area near the factory. The total number of questionnaires targeted to the exposed area was 130, and to the unexposed area 150.

The data on health conditions were gathered by means of a family questionnaire administered to a qualified informant, defined as an adult resident with responsibility in the household who could supply the desired information. The questionnaire was constructed to identify all the members of the household, determine their lengths of residence in the area, and investigate each one's experience of nonspecific signs and symptoms (irritation of the eyes and respiratory tract, sleep disturbances), acute illnesses (acute otitis), chronic diseases (bronchitis, allergies, skin problems, cancers), pregnancy complications (threatened abortion, spontaneous abortion, premature delivery, and low birthweight), and congenital diseases or malformations. To maximize precision, questions about nonspecific signs and symptoms and acute illnesses referred only to those present at the time of the interview. In contrast, questions about chronic diseases referred to any that had occurred at any time during residence in the study area. At the end of the interview, the informant was asked if he or she associated the family's health problems with pollution from any local factories, and if so, which plant.

The questionnaire was administered by specially trained psychology students. To avoid observer bias (25), the objective of the study was concealed from the interviewers. Rather than being told that the objective was to identify the health effects of emissions from the recycling plant, they were told that it was to understand the overall effects of environmental pollution in various communities in the Monterrey metropolitan area. This was done to assure that there would be no differences in the interviewing approaches to the exposed and unexposed informants.

The data were processed with the program dBase III-plus. The statistical analyses were carried out using Epi Info 5.1. The analysis consisted of calculating the frequencies of the principal ailments and diseases in the two populations and testing for significant differences. The relative odds of the problems in the exposed and unexposed groups were compared by calculating prevalence ratios, along with their $95 \%$ confidence intervals.

\section{RESULTS}

In the exposed group, 127 questionnaires were administered and information was obtained on 596 individuals. Among the unexposed, 147 questionnaires were administered collecting information on 743 individuals. Thus, interviews were obtained in almost all the residences called for in the study design. No interviewee declined to give information. Nonresponse occurred only in cases where no one was found at home.

Among the exposed population, $50.7 \%$ were women and $49.3 \%$ men. In the unexposed group, the percentages were $49.7 \%$ and $51.3 \%$, respectively. The age distributions in the exposed and unexposed groups were similar, and no statistically significant difference was observed between the proportions of exposed and unexposed persons in any age group. The average duration of residence was 8.5 years among the exposed, and 11.0 years among the unexposed.

Of the qualified informants in the exposed group, $66.7 \%$ declared that their ailments were due to pollutants emanating from some factory, and $48 \%$ identified the neighborhood plant as the source. Among the unexposed informants, $12.9 \%$ associated their ail- 
ments with emissions from a nearby factory, and only $2.8 \%$ pointed to a specific factory.

The health problems reported most frequently by the exposed were irritation of the eyes and upper respiratory tract, allergies, sleep disturbances, bronchitis, fatigue, skin problems, ear infections, and anemia. Among the unexposed, the same problems were observed, although with lower frequencies (Table 2). The proportions of smokers in each group were similar (10.4\% among the exposed and $11.2 \%$ among the unexposed). The rates of skin eruptions and diseases, excessive tiredness, sleep problems, upper respiratory infections, bronchitis, otitis, and allergies were higher for the exposed than the unexposed (Table 2). ${ }^{3}$

To control for possible confounding, prevalence rates were adjusted for the duration of residence in the area. The resulting prevalence estimates were not significantly different from the unadjusted estimates. In addition, the prevalence rates of eye irritation and upper respiratory tract infection were adjusted for smoking, and the resulting value $(1.8,95 \% \mathrm{CI}: 1.3-2.4)$ was very similar to the unadjusted one. No differences were observed between the crude and age-adjusted prevalence rates of any health problems.

The study and control populations' prevalence ratios for the problems under investigation appear in Table 3 disaggregated by sex. Compared to their unexposed counterparts, the exposed men and women had higher prevalences of skin problems, otitis, excessive tiredness, sleep disturbances, and allergies. The prevalence ratios for most of the problems were higher for the men.

Table 4 shows that the data do not demonstrate differences in exposed and unexposed women's prevalences of obstetrical problems, abortions, or

\footnotetext{
3 As can be seen, this table includes prevalence ratios whose confidence intervals include the value 1.0. The prevalences of some problems may have been underestimated in either or both groups because of the low sensitivity of the data gathering instrument. Anemia was omitted because no cases were found among the unexposed individuals.
}

TABLE 2. Prevalences and prevalence ratios for health problems in the study and control populations. Nuevo León, Mexico, 1994

\begin{tabular}{|c|c|c|c|c|c|}
\hline \multirow[b]{2}{*}{ Problem } & \multicolumn{2}{|c|}{ Exposed } & \multicolumn{2}{|c|}{ Unexposed } & \multirow[b]{2}{*}{ Prevalence ratio $(95 \% \mathrm{Cl})$} \\
\hline & No. & $\%$ & No. & $\%$ & \\
\hline \multicolumn{6}{|c|}{$\begin{array}{l}\text { Irritation of the eyes } \\
\text { and upper respiratory }\end{array}$} \\
\hline tract & 103 & 17.3 & 66 & 8.8 & $1.9(1.5-2.6)$ \\
\hline Allergy & 92 & 15.4 & 82 & 11.0 & $1.5(1.1-2.0)$ \\
\hline Sleep disturbance & 52 & 8.7 & 28 & 3.7 & $2.3(1.5-4.0)$ \\
\hline Bronchitis & 49 & 8.2 & 34 & 4.6 & $1.8(1.2-2.7)$ \\
\hline Excessive fatigue & 42 & 7.0 & 19 & 2.5 & $2.8(1.6-4.7)$ \\
\hline Skin problems & 36 & 6.0 & 20 & 2.7 & $2.2(1.3-3.8)$ \\
\hline Skin eruptions & 36 & 6.0 & 16 & 2.2 & $2.8(1.6-5.0)$ \\
\hline Otitis & 44 & 7.4 & 18 & 2.4 & $2.5(1.4-4.3)$ \\
\hline Anemia & 8 & 1.3 & 0 & 0 & $-\quad(-)$ \\
\hline Asthma & 23 & 3.8 & 24 & 3.2 & $1.2(0.7-2.1)$ \\
\hline Nephropathy & 21 & 3.5 & 23 & 3.0 & $1.1(0.6-2.0)$ \\
\hline Hernia & 16 & 2.6 & 15 & 2.0 & $1.3(0.6-2.7)$ \\
\hline Liver dysfunction & 4 & 0.6 & 3 & 0.4 & $1.6(0.3-9.4)$ \\
\hline
\end{tabular}

TABLE 3. Prevalence ratio, by sex, of health problems in the study and control populations. Nuevo León, Mexico, 1994

\begin{tabular}{lcc}
\hline \multirow{2}{*}{\multicolumn{1}{c}{ Problem }} & \multicolumn{2}{c}{ Prevalence ratio $(95 \% \mathrm{Cl})$} \\
\cline { 2 - 3 } & \multicolumn{1}{c}{ Females } & Males \\
\hline Skin problems & $3.8(1.6-8.7)$ & $1.4(1.0-3.1)$ \\
Otitis & $2.7(1.3-5.6)$ & $5.6(2.3-15.6)$ \\
Skin eruptions & $2.1(1.0-4.8)$ & $3.5(1.4-9.4)$ \\
Sleep disturbance & $2.6(1.4-4.9)$ & $2.6(1.3-5.1)$ \\
Allergy & $1.5(1.1-2.1)$ & $1.7(1.1-2.5)$ \\
Excessive fatigue & $2.5(1.3-4.9)$ & $3.3(1.3-8.3)$ \\
Irritation of the eyes and upper & & $2.1(1.4-3.1)$ \\
\hline
\end{tabular}

babies with congenital malformations or low birthweight.

\section{DISCUSSION}

This study has limitations that could affect its validity. The lack of a random sample could have introduced selection bias. However, the sample size is sufficient to be considered representative of the exposed population (26). Moreover, the number of interviewees amounts to nearly all the households in the exposed area.

Exposures were not evaluated over time and different degrees of exposure could not be distinguished. As a result, it was necessary to imagine that all interviewees had similar exposures, and it was impossible to identify subgroups with higher risks among the exposed population.

Confounding due to exposure to atmospheric pollutants was controlled by comparing two populations who were subject to similar levels of general environmental pollution, but different exposures to industrial toxins. The relatively high proportion of informants who attributed their family's health conditions to pollution from the factories is an additional datum in support of a relationship.

Biases can be introduced in the course of gathering information. In this 
TABLE 4. Prevalences and prevalence ratios for reproductive problems among women in the study and control populations. Nuevo León, Mexico, 1994

\begin{tabular}{lrrrrrrrr}
\hline & \multicolumn{2}{c}{ Exposed } & & \multicolumn{2}{c}{ Unexposed } & & \\
\cline { 2 - 3 } Reproductive problem & No. & $\%$ & & No. & $\%$ & & Prevalence ratio $(95 \% \mathrm{Cl})$ \\
\hline Spontaneous abortion & 13 & 11.2 & & 8 & 5.6 & 1.9 & $(0.8-4.6)$ \\
Threatened abortion & 8 & 6.8 & & 6 & 4.2 & 1.6 & $(0.6-4.5)$ \\
Congenital malformation & 4 & 3.4 & & 2 & 1.4 & & 2.4 & $(0.5-13.1)$ \\
Premature birth & 3 & 2.5 & & 10 & 7.0 & & 0.4 & $(0.1-1.3)$ \\
Low birthweight & 2 & 1.7 & & 2 & 1.4 & & 1.2 & $(0.2-8.5)$ \\
\hline
\end{tabular}

study, the possibility of observer bias can be dismissed, as the interviewers did not know the purpose of the study. Moreover, the questionnaire was designed to avoid conveying to interviewees the idea that their health problems were due to factory pollution.

The questionnaire has weak power to elicit revelations of health problems, so some diseases may have been underestimated. Bias may also have occurred owing to forgetfulness or lack of knowledge on the part of the informants. Although such biases were probably similar in the exposed and unexposed groups, and therefore their impacts should have canceled out, they may also have led to underestimation of disease risks (27).

The similar frequencies of chronic diseases detected in both study groups National Research Council. Environmental epi-
demiology. Washington, DC: National Academy Press; 1991.

2. British Medical Association. Hazardous waste and human health. Oxford: Oxford University Press; 1990.

3. Hertzman CM. Upper Ottawa landfill site health study. Environ Health Perspect 1987;75: 173-195.

4. Neuberger JS, Mulhall M, Pomatto MC, Sheverbush J, Hassanein RS. Health problems in Galena, Kansas (USA): a heavy metal mining superfund site. Sci Total Environ 1990;94: 261-272.

5. Ozonoff DM, Colten ME, Cupples A, Heeren $\mathrm{T}$, Schatzkin A, Mangione T, et al. Health problems reported by residents of a neighborhood contaminated by a hazardous waste facility. Am J Ind Med 1987;11:581-597.

6. Lagakos SW, Wenssen BJ, Zelen M. An analysis of contaminated well water and health

may be attributable to the generally high rate of chronic disease in this population, as was suggested by the pattern of mortality in the state of Nuevo León. That is, toxic effects produced by the exposures considered in this study may have been subsumed in the mix of chronic diseases produced by other factors. Future studies should explore the possibility of such masking.

The lack of differences between the crude prevalence ratios and those adjusted for duration of residence in the area is likely explained by the types of diseases and problems reported, which were mostly acute or subacute. The same applies to the effects of age, and smoking. The shorter the duration of residence in the area, the lower the chances of developing such illnesses

\section{REFERENCES}

effects in Woburn, Massachusetts. J Am Stat Assoc 1986;81:583-596.

7. Goldberg SJ, Lebowitz MD, Graver EJ, Hicks $\mathrm{S}$. An association of human congenital cardiac malformations and drinking water contaminants. J Am College Cardiol 1990;16:155-164.

8. Harris R, Rodricks J, Clarck S, Papadopoulos $S$. Adverse health effects at a Tennessee hazardous waste disposal site. In: Andelman J, Underhill D. Health effects from hazardous waste sites. Chelsea, Michigan: Lewis; 1990:221-240.

9. Stebbins KR. Garbage imperialism: health implications of dumping hazardous waste in Third World countries. Med Anthropol 1992; 15:81-102

10. Manahan S. Hazardous waste chemistry, toxicology and treatment. Chelsea, Michigan: Lewis; 1990.

11. Cralley LV, Cralley LJ. Volume I: Process flows. In: Industrial hygiene aspects of plant operation. New York: Macmillan; 1982. associated with toxic exposures as slow-growing tumors. Also, it is important to recognize the difficulty of gathering reliable information on reproductive problems. Their frequency may have been underestimated.

On the other hand, some individuals whose chronic illnesses were produced or aggravated by toxic emissions in the area may have been lost to the study. Some may have left the zone, for example, to escape symptoms of respiratory diseases caused by toxic substances. In this scenario, exposed cases alone would be lost, resulting in an underestimation of the exposure-disease association.

These results suggest that the individuals exposed to toxic emissions from the recycling plant have an elevated risk of harmful health effects, compared to unexposed persons.

Acknowledgment. The author thanks Fernando Bejarano, representative of the Campaña de la Oficina de Tóxicos de Greenpeace-México, Raúl Rubio Cano, Juan de Dios Sánchez Martínez, and Federico Lazcano Ramírez for their enthusiasm and support, as well as everyone who helped obtain the required data.
12. Heith L, Walters D. Volume III: Standards and regulations. In: The National Toxicology Program. Chelsea, Michigan: Lewis; 1992.

13. Lewis R. Hazardous chemicals: desk reference. New York: Van Nostrand Reinhold; 1993.

14. Lippman M. Environmental toxicants. New York: Van Nostrand Reinhold; 1991.

15. Landrigan P. Occupational and community exposures to toxic metals: lead, cadmium, mercury, and arsenic. Western J Med 1982;11: 531-539.

16. Gossed T, Briker D. Principles of clinical toxicology. New York: Raven Press; 1990:162-193.

17. Academia Americana de Pediatría. Intoxicación por plomo: de la detección a la prevención primaria. Salud Publica Mex 1995;37: 264-275.

18. Agency for Toxic Substances and Disease Registry. Toxicological profile for lead. Atlanta: United States Department of Health and Human Services; 1993. 
19. Agency for Toxic Substances and Disease Registry. Public health assessment: guidance manual. Chelsea, Michigan: Lewis; 1992.

20. Agency for Toxic Substances and Disease Registry. The Crystal Chemical Company: arsenic exposure study. Houston: ATSDR, Epidemiology and Medicine Branch; 1989.

21. LaGoy P, Nisbet I, Schultz C. The endangerment assessment for the Smuggler Mountain site, Pitkin County, Colorado. In: Paustenbach $\mathrm{D}$. The risk assessment of environmental and human health hazards. New York: John Wiley and Sons; 1989:505-525.
22. Instituto Nacional de Estadística, Geografía e Informática. Tabulaciones por defunciones. Mexico, DF: INEGI; 1990.

23. Kleinbaum DG, Kupper LL, Morgensten H. Epidemiologic research. New York: Van Nostrand Reinhold; 1982.

24. Fleiss J. Statistical methods for rates and proportions. New York: John Wiley and Sons; 1985.

25. Andersson N. Distractores y modificadores de efecto: conceptos claves en la epidemiología moderna. Prioridades Salud. 1991;2: 30-35.
26. Andersson N. Los problemas con el muestro probabilístico en la selección de los sitios centinela. Prioridades Salud. 1991;2:30-35.

27. Kaye WE, Hall HI, Lybarger JA. Recall bias in disease status with perceived exposure to hazardous substances. Ann Epidemiol 1994;4: 393-397.

Manuscript received on 3 April 1996. Revised version accepted for publication on 27 January 1997.

RESUMEN El presente estudio se realizó en México en una población vecina a una planta recicladora de cinc y de otros polvos metálicos ante la posibilidad de que estas sustancias entraran en contacto con la población y produjeran diferentes efectos nocivos sobre la salud. La planta se sitúa en un municipio cercano a Monterrey, que es la tercera ciudad más poblada de México y la segunda más industrializada.

Se aplicó un diseño transversal comparativo para llevar a cabo la investigación, que duró de septiembre a noviembre de 1994. Mediate un muestreo por cuotas se seleccionaron viviendas en dos zonas - una zona expuesta por vecindad a la planta y otra no expuesta que sirvió de control- hasta lograr el tamaño muestral deseado (621 individuos, a un promedio de cinco por vivienda). En cada domicilio un estudiante de psicología adiestrado aplicó un cuestionario a un familiar mayor de edad para recoger datos sobre la presencia de afecciones agudas y crónicas, trastornos del embarazo y enfermedades congénitas en los integrantes del hogar.

En la población expuesta se aplicaron 127 cuestionarios, que arrojaron información sobre 596 personas, y en la población no expuesta se administraron 147, que proporcionaron datos sobre 743 personas. Las distribuciones por sexo y edad fueron semejantes en las dos poblaciones y el tiempo de residencia en la zona fue ligeramente mayor en los individuos no expuestos.

Los problemas de salud más frecuentes en la población expuesta fueron irritación ocular y de vías respiratorias superiores, alergias, trastornos del sueño, bronquitis, cansancio excesivo, problemas cutáneos, otitis y anemias. Las razones de prevalencias fueron significativas en el caso de erupciones y otras enfermedades cutáneas, cansancio excesivo, trastornos del sueño, infecciones respiratorias superiores, otitis, bronquitis y alergias. Cuando se compararon los dos grupos de mujeres no se encontraron diferencias significativas en las prevalencias de problemas obstétricos, abortos espontáneos o hijos con malformaciones congénitas o bajo peso al nacer.

La sensibilidad del cuestionario utilizado para detectar problemas de salud es pobre y podría haber causado una subestimación de algunas afecciones. No obstante, diferentes sesgos de información fueron controlados y ello permite concluir que la población expuesta tiene un mayor riesgo de padecer ciertas enfermedades y trastornos que la población no expuesta. 